PROBLEMS OF NATIONAL PUBLIC AND PRIVATE LAW

DOI: 10.46340/eppd.2021.8.6.9

Iryna Zavydniak, PhD in Law

ORCID ID: https://orcid.org/0000-0003-1816-7426

University of State Fiscal Service of Ukraine

\title{
SUBJECTS OF INTERACTION AND THE LEVEL OF ITS SUPPORT IN INVESTIGATION OF ECONOMIC CRIMES OF A TRANSNATIONAL CHARACTER
}

Ірина Завидняк, к. ю. н.

Університет державної фіскальної служби України

\section{СУБ'ЄКТИ ВЗАСМОДІЇ ТА РІВНІ ЇЇ ЗАБЕЗПЕЧЕННЯ ПРИ РОЗСЛІДУВАННІ ЕКОНОМІЧНИХ ЗЛОЧИНІВ ТРАНСНАЦІОНАЛЬНОГО ХАРАКТЕРУ}

The article examines the system of interactions between the competent authorities around the world in the investigation of economic crimes of transnational nature. The concept of interaction in the investigation of transnational crimes and its forms is defined. Situations in which cooperation in the investigation of transnational economic crimes is necessary are indicated, namely: search for evidence and search for persons outside the territory of Ukraine; lack of indicative information; lack of expert methods; the need for expert equipment, relevant materials, resources; lack of relevant data in registration and forensic records; counteraction by corrupt structures, criminals and other interested persons in the stage of committing a crime and its investigation. The levels of cooperation in the investigation of transnational economic crimes are analyzed, including heads of state and government and other senior officials; Diplomatic representatives of states; authorized (central) bodies; international organizations; competent (law enforcement) authorities. Emphasis is placed on such a level of cooperation as international organizations. It is noted that for most international organizations, cooperation in the investigation of transnational economic crimes is not the purpose of creation and operation. At the same time, among them are those for whom participation in cooperation in the investigation of crimes of this category or its individual areas are the purpose of the creation and one of the activities. Such international organizations include the International Criminal Police Organization (Interpol), the European Police Organization (Europol) and the European Organization for Justice (Eurojust). No less important role in the process of cooperation in the investigation of transnational economic crimes is assigned to such a competent authority as the State Financial Monitoring Service of Ukraine. Thus, based on a request from a detective (investigator), the financial intelligence authority requests financial information from the financial intelligence units of a foreign state, which in turn receives this information from the subject of primary financial monitoring and provides it for use in investigating transnational economic crimes. Examining the current state of the system of cooperation in the investigation of transnational crimes, it is determined that the main activity of central authorities, competent authorities and specialized international organizations in Ukraine is not joint activities of officials in investigating such crimes, and information exchange by such persons.

Keywords: interaction, economic crimes of a transnational nature, international organizations, central authorities, competent authorities, information exchange.

Постановка проблеми. Зміни у характері та масштабах злочинної економічної діяльності, зумовили розвиток системи взаємодій між компетентними органами різних країн світу 
під час розслідування економічних злочинів транснаціонального характеру. Така ситуація вимагає вжиття заходів найрізноманітнішого характеру, й має бути заснована на докорінній зміні процесу розслідування злочинів даної категорії, який у цей період стає більш науково обгрунтованим, пов'язаним з використанням сучасних інформаційних технологій та знань.

Основною метою даної статті є спроба комплексного наукового дослідження системи взаємодії при розслідуванні економічних злочинів транснаціонального характеру; визначення суб'єктів забезпечення взаємодії при розслідуванні таких злочинів.

Аналіз останніх досліджень і публікацій. Увагу питанням взаємодії компетентних органів при розслідуванні транснаціональних злочинів приділяли А.В. Даниляк, О.В. В'язовченко, І.В. Лєшукова, Є.М. Карпенко, В.П. Корж, О.С. Користін, В.А. Некрасов, Н.В. Павлова, А.П. Слободзян, В.М. Федченко, С.С. Чернявський, Ю.М. Чорноус, та ін. Дослідження даної проблематики також неможливе без вивчення та аналізу процесуальних законодавчих актів та положень міжнародних договорів.

Виклад основного матеріалу. Розглядаючи особливості організації взаємодії компетентних органів нашої держави та компетентних органів іноземних держав при розслідуванні економічних злочинів транснаціонального характеру, необхідно зазначити про неможливість простого копіювання досвіду організації взаємодії учасників кримінального судочинства, що здійснюється у рамках законодавства на території України або на території іншої держави. Тому, на перший план має висуватись завдання його творчої переробки та адаптації. Взаємодія, під час розслідування транснаціональних злочинів, $\epsilon$ своєрідною надбудовою над цілісною системою взаємодії компетентних органів кожної конкретної держави.

Взаємодія при розслідуванні транснаціональних економічних злочинів, як і взаємодія при розслідуванні загальнокримінальних злочинів, вчинених на території України, з погляду української правової доктрини, здійснюється у формі інформаційного обміну, а саме, шляхом направлення запитів про правову допомогу, екстрадицію, про перейняття кримінального провадження, про створення спільних слідчих груп або присутності представників компетентних органів іноземних держав при проведенні процесуальних дій та шляхом направлення прохання про тимчасову передачу особи.

У зв'язку з цим, пропонуємо, взаємодію правоохоронних органів під час розслідування транснаціональних злочинів розглядати, як комунікацію та спільну діяльність конкретних службових осіб правоохоронних та компетентних органів, інших посадових осіб іноземних держав та України в ході організації та здійснення розслідування, а також деякі аспекти їхньої діяльності поза рамками конкретних розслідувань.

Така взаємодіє безперечно може мати й непроцесуальний характер. Наприклад, Ю. М. Чорноус виділяє такі неформальні методи співробітництва під час розслідування транснаціональних злочинів, як консультування представників окремих підрозділів та надання інформації довідкового характеру ${ }^{\text {. }}$ Відзначимо, що непроцесуальний обмін інформацією може відбуватись між окремими службовими особами - представниками компетентних або правоохоронних органів держав й значною мірою грунтується на особистих зв'язках.

Ефективна взаємодія при розслідуванні економічних злочинів транснаціонального характеру, також тісно пов'язана й з обміном досвідом, науково-педагогічним співробітництвом, узагальненням досвіду співробітництва, особливо в умовах, коли будь-які особисті контакти 3 посадовими особами компетентних органів іноземних держав суворо регламентовані та обмежені.

Такі форми взаємодії організовуються компетентними органами держав та виходять за рамки безпосередньої взаємодії при розслідуванні транснаціональних злочинів, але якраз $є$ підгрунтям високої ефективності взаємодії, та по суті спрямовані на подолання багатьох формальних обмежень офіційного міжнародного співробітництва, що робить взаємодію більш безпосередньою та комунікативною.

Окреслення форм взаємодії компетентних органів України з іноземними компетентними органами при розслідуванні економічних транснаціональних злочинів дає нам можливість визначити ті ситуації, у яких взаємодія є необхідною, а саме: пошук доказів та розшук осіб поза територією України (необхідність перевірки доказів та версій вчинення злочинів даної категорії); відсутність інформації орієнтуючого характеру; відсутність експертних методик, необхідність експертного обладнання, відповідних матеріалів, ресурсів; відсутність відповідних даних у реєстраційних

\footnotetext{
1 Чорноус, Ю. М. (2012). Теорія і практика криміналістичного забезпечення досудового слідства у справах про злочини міжнародного характеру. Київ: Скіф, 190-191.
} 
та криміналістичних обліках; протидія з боку корумпованих структур, злочинців та інших зацікавлених осіб на стадії вчинення злочину та його розслідування.

Учасниками такої взаємодії при розслідуванні транснаціональних злочинів $є$ конкретні службові особи правоохоронних та компетентних органів держав, що співпрацюють. Так, відповідно до Кримінального процесуального кодексу України суб'єктами взаємодії при розслідуванні транснаціональних економічних злочинів зі сторони України є суди (першої, апеляційної та касаційної інстанції), органи прокуратури в особі відповідних прокурорів, органи досудового розслідування, що здійснюють контроль за додержанням податкового законодавства в особі слідчих та керівників таких органів, детективів Національного антикорупційного бюро України, а з іншого боку, - відповідні компетентні органи та службові особи іноземних держав.

Зазначимо, що ці суб'єкти можуть надсилати запит лише у кримінальному провадженні, яке вони здійснюють, тобто суд - лише у судовому провадженні, а прокурор, слідчий або детектив тільки у досудовому розслідуванні.

Ключовою для класифікації суб'єктів взаємодії при розслідуванні злочинів транснаціонального характеру є ознака повної або часткової відповідності компетенції суб'єктів взаємодії, оскільки правова природа взаємодії полягає у передачі компетенції, обумовленої нормами національного законодавства, тобто суб'єкт, який ініціює взаємодію у певних ситуаціях та формах, повинен мати належні повноваження для ініціювання такої взаємодії та розслідування злочинів певних категорій на власній території. Суб’єкт, що представляє іншу країну, повинен мати такі повноваження, які дадуть йому можливість діяти необхідним для запитуючої сторони способом або навіть застосувати законодавство сторони, що запитує.

Аналіз законодавства та слідчої практики свідчить про те, що слідчий (детектив) немає права й часом не готовий безпосередньо взаємодіяти з іноземними «компетентними органами» та іншими учасниками взаємодії з питань, що лежать поза його звичних процесуальних повноважень, і навіть професійних знань, умінь та навичок. Тому, необхідно виділити тих суб'єктів, які на різних рівнях міжнародних відносин забезпечують ефективну взаємодію при розслідуванні транснаціональних злочинів.

Забезпечення взаємодії при розслідуванні економічних злочинів транснаціонального характеру здійснюється на наступних рівнях: глави держав та урядів, інші вищі посадові особи; Дипломатичні представники держав; уповноважені (центральні) органи; міжнародні організації; компетентні (правоохоронні) органи.

Сучасний період відзначається тим, що особливу роль в організації та забезпеченні боротьби 3 економічними злочинами транснаціонального характеру відіграють глави держав та урядів або інші вищі посадові особи. Політичні та економічні відносини між державами безпосередньо визначають можливість та ефективність взаємодії компетентних органів держав при розслідуванні та запобіганні транснаціональних економічних злочинів. Домовленості, досягнуті на найвищому рівні, поширюють свою дію на всю сферу правоохоронної діяльності ${ }^{1}$.

У свою чергу, Дипломатичні представники держав забезпечують взаємодію шляхом організації на двосторонній та багатосторонній основі масштабного й відкритого обговорення актуальних питань боротьби з економічною злочинністю; координують розробку міжнародних договорів, угод та рекомендацій (декларацій) у даній сфері; збирають політичну, економічну, ділову та іншу інформацію, доступну в країні перебування закордонного представництва (забезпечують ії переклад та первинний аналіз); налагоджують робочі контакти з посадовими особами іноземних держав; організовують зустрічі експертів, освітні та дослідницькі програми. Дипломатичні представники $\epsilon$ посередниками в інформаційному обміні між компетентними органами держав, створюючи таким чином дипломатичні канали інформаційного обміну на засадах взаємності ${ }^{2}$.

Своєрідність дипломатичних каналів інформаційного обміну зумовлена тим, що відповідно до наявної дипломатичної практики, кореспонденція на паперовому носії з України передається в розташоване у державі-адресаті дипломатичне представництво України, яке в особі посла або іншої повноважної особи у рамках регулярних (зазвичай 1 або 2 рази на місяць) робочих зустрічей 3 представниками дипломатичного відомства іноземної держави передає їм ії виходячи з ноти. Запит (нота) може бути переданий у позачерговому порядку у разі наявності спеціальної вказівки Міністра

\footnotetext{
1 Леган, I. М. (2021). Основні напрями й форми міжнародного співробітництва щодо запобігання та протидії транснаціональній злочинності. Актуальні проблеми держави і права, 90, 89-93.

2 Флісак, К. А. (2013). Економічна дипломатія. Тернопіль: Новий колір, 65.
} 
закордонних справ або його заступника. На терміни інформаційного обміну впливають і способи їх фактичної доставки в розпорядження дипломатичного представництва. Термін передачі кожного запиту про правову допомогу дипломатичними каналами в абсолютній більшості випадків значно перевищує термін передачі такого запиту через посередництво центральних органів і займає зазвичай до 2 місяців.

Наступним рівнем забезпечення взаємодії при розслідуванні транснаціональних економічних злочинів $\epsilon$ уповноважені (центральні) органи. Відповідно до кримінального процесуального законодавства України центральними органами у процесі міжнародного співробітництва під час кримінального провадження є Офіс Генерального прокурора України, Національне антикорупційне бюро України, яке виконує функції центрального органу України під час досудового розслідування корупційних та фінансових злочинів та Міністерство юстиції України.

Зазначимо, що рішення в процесі надання та отримання міжнародної правової допомоги у кримінальному провадженні можуть бути прийняті не тільки уповноваженим (центральним) органом України, а й уповноваженим органом нашої держави. Різниця полягає в тому, що у процесі безпосередніх зносин, уповноважений орган нашої держави наділено далеко не всіма повноваженнями уповноваженого (центрального) органу України. Так, у ч. 4 ст. 554 КПК України наведено перелік рішень, які може приймати виключно центральний орган України і які не можуть бути віднесені до компетенції уповноваженого органу.

До компетенції центральних та уповноважених органів під час розгляду запитів про міжнародну правову допомогу, можна віднести: прийняття та організація виконання запиту іноземного компетентного органу, який надійшов від запитуючої сторони електронною поштою, факсимільним або іншим засобом зв'язку (ч. 5 ст. 548 КПК України); надання вказівок компетентним органам України 3 метою якісного виконання у стислий термін іноземного запиту про міжнародну правову допомогу увигляді проведення процесуальних дій (ч. 3 ст. 554 КПК України); узгодження із запитуючою стороною порядку виконання клопотання із певними обмеженнями або умовами за наявності підстав для відмови узадоволенні запиту або для його відкладення (ч. 3 ст. 555 КПК України); перевірка належного оформлення, повноти та якості матеріалів, отриманих українськими компетентними органами за результатами виконання іноземного запиту, за необхідності - вжиття додаткових заходів до виконання клопотання у повному обсязі ${ }^{1}$.

Отже, основними функціями центрального та уповноваженого органів України у процесі надання міжнародної правової допомоги конкретній іноземній державі, є контроль та організація інформаційного обміну доказовою інформацією між компетентними органами різних держав.

Також, варто зазначити, що статус уповноваженого (центрального) органу України та уповноваженого органу при реалізації безпосередніх зносин з надання міжнародної правової допомоги із конкретними державами чи при розслідуванні певної категорії злочинів, може бути уточнений або встановлений міжнародними договорами або навіть законами про ратифікацію міжнародних договорів. На підставі відомчих нормативно-правових актів, відповідний уповноважений орган визначає ті підрозділи й тих службових осіб, які й реалізовуватимуть функції «центрального органу».

Канали центральних органів України $є$ основними для направлення та отримання запитів щодо міжнародної правової допомоги, передачі їх результатів.

Наступним рівнем забезпечення взаємодії під час розслідування транснаціональних економічних злочинів $\epsilon$ міжнародні організації. Відповідно до доктрини міжнародного права, міжнародна організація - це об'єднання держав, створене на основі міжнародного договору для виконання певних цілей, що має систему постійно діючих органів, володіє міжнародною правосуб'єктністю та засноване відповідно до міжнародного права.

На нашу думку, до міжнародних організацій - учасників системи взаємодії при розслідуванні злочинів транснаціонального характеру, можна віднести не тільки ті, які мають право брати участь у взаємодії при розслідуванні злочинів, а насамперед ті, які, як правило, опосередковано забезпечують різнобічну підтримку взаємодії при розслідуванні.

Для більшості міжнародних організацій взаємодія під час розслідування транснаціональних економічних злочинів не $є$ метою створення та діяльності. Разом з тим, серед них можна виділити ті,

\footnotetext{
${ }^{1}$ Кримінальний процесуальний кодекс Украӥни, 2012 (Верховна Рада України). Офіційний сайт Верховної Ради України <https://zakon.rada.gov.ua/laws/show/4651-17\#Text> (2021, листопад, 10).
} 
для яких участь у взаємодії під час розслідування економічних злочинів транснаціонального характеру або окремі iї напрями $\epsilon$ метою створення та одним із видів діяльності. До таких міжнародних організацій необхідно віднести Міжнародну організацію кримінальної поліції (Інтерпол), Європейську поліцейську організацію (Європол) та Європейську організацію з питань юстиції (Свроюст $)^{1}$.

Так, Інтерпол - глобальна міжнародна організація правоохоронних органів практично всіх країн світу, яка виникла до формування більшості сучасних регіональних міжнародних організацій, забезпечує поповнення централізованих криміналістичних обліків; підтримує систему інформаційного обміну та орієнтуючої інформації; розробляє відповідні технічні вимоги та правила; організовує навчання співробітників правоохоронних органів різних країн; проводить публічне та непублічне обговорення всіх питань міжнародного співробітництва усфері кримінального судочинства тощо. У цьому механізмі взаємодії, Інтерпол діє як єдиний світовий центр щодо вироблення спільної поліцейської стратегії та тактики боротьби з міжнародною злочинністю

Зазначимо, що Інтерпол, не може проводити самостійні розслідування злочинів, у тому числі економічних злочинів транснаціонального характеру та здійснювати розшук злочинців у різних країнах світу.

Взаємодія правоохоронних органів України з НЦБ Інтерполу України при розслідуванні економічних злочинів транснаціонального характеру включає в себе не лише обмін необхідною для подальшого розслідування інформацією, а й проведення міжнародного розшуку, екстрадиції та надання допомоги при проведенні процесуальних дій у межах міжнародного співробітництва. Варто відмітити, що у кримінальних провадженнях щодо економічних транснаціональних злочинів у сфері оподаткування, екстрадиція буде можливою лише за умови, що ухилення від оподаткування буде пов'язане зі злочинами, санкції яких передбачають покарання у виді позбавлення волі.

Як бачимо, Інтерпол виділяється серед міжнародних організацій правоохоронних органів глобальним характером.

Ще однією спеціалізованою міжнародною організацією, яка є суб'єктом забезпечення взаємодії при розслідуванні транснаціональних економічних злочинів, $є$ Свропейська поліцейська організація Європол. Діяльність Європола аналогічна діяльності Інтерполу, але спрямована на безпосереднє задоволення інтересів країн Свропейського Союзу у сфері попередження та боротьби з найбільш небезпечними видами транснаціональної злочинності. Так, напрямами роботи Європолу є: інформаційне сприяння державам-членам у розслідуванні злочинів; науково-технічне сприяння; координація роботи національних слідчих органів ${ }^{2}$.

При розслідуванні економічних злочинів транснаціонального характеру також доволі важливою є взаємодія з Свропейською організацією з питань юстиції - Свроюстом. Метою створення Євроюсту є підвищення ефективності діяльності правоохоронних органів країн - членів СС у сфері розслідування та судового переслідування особливо небезпечних міжнародних злочинів.

Держави, які не $\epsilon$ членами Європейського Союзу, але $є$ сторонами Європейської конвенції про захист осіб у зв'язку з автоматизованою обробкою персональних даних від 28.01.1981 р., можуть укладати двосторонні договори з Свроюстом, щодо обміну інформацією та направлення офіцерів зв'язку.

Поряд 3 цим, варто також відмітити такі міжнародні організації як Організація економічного співробітництва та розвитку (ОЕСР), Всесвітня митна організація (BMO), Внутрішньо-європейська організація податкових адміністрацій (IOTA). Однак, їх діяльність обмежується розробкою міжнародних інструментів щодо податкового та митного законодавства й наданні допомоги загального характеру у сфері оподаткування й митної справи, але не забезпечує взаємодію при розслідуванні злочинів даної категорії.

Як бачимо, на відміну від попередніх рівнів, саме центральні органи та спеціалізовані міжнародні організації забезпечують суто спеціальні та практичні питання взаємодії під час розслідування транснаціональних економічних злочинів. Ця діяльність базується на результатах співробітництва дипломатичного та вищого рівнів, заснована на виконанні міжнародних договорів та врегульована національним законодавством України.

\footnotetext{
${ }^{1}$ В'язовченко, О. В. (2018). Особливості співпраці України з міжнародними організаціями під час розслідування ухилень від сплати податків транснаціонального характеру. Науковий вісник Ужгородського національного університету, 48, 99-102.

${ }^{2}$ Карпенко, С. М. (2011). Участь Сврополу в запобіганні та протидії транснаціональній злочинності: правові та організаційні засади. Науковий вісник Київського національного університету внутрішніх справ, 2, $322-328$.
} 
Останнім рівнем забезпечення взаємодії під час розслідування економічних злочинів транснаціонального характеру є діяльність окремих компетентних (правоохоронні) органів.

На нашу думку, саме на цьому рівні взаємодії, доволі важливою та вагомою є діяльність органів фінансової розвідки. Згідно із Законом України «Про ратифікацію Конвенції Ради Європи про відмивання, пошук, арешт та конфіскацію доходів, одержаних злочинним шляхом, та про фінансування тероризму» Державна служба фінансового моніторингу України (Держфінмоніторинг) є органом, уповноваженим Україною на виконання функцій підрозділу фінансової розвідки ${ }^{1}$.

Вважаємо, що Держфінмоніторинг $є$ учасником непроцесуальної форми взаємодії при розслідуванні злочинів даної категорії, так званим посередником слідчого або детектива в отриманні аналітичної або розвідувальної інформації. Держфінмоніторинг здійснює аналіз інформації, одержуваної з фінансової системи держави та інформує правоохоронні та контролюючі органи про наявні ознаки злочинів або іншої протиправної діяльності, надає доказову інформацію або підтверджуючі матеріали.

На підставі запиту слідчого (детектива) орган фінансової розвідки запрошує інформацію фінансового характеру у підрозділу фінансової розвідки іноземної держави, яка у свою чергу отримує цю інформацію від суб'єкта первинного фінансового моніторингу (конкретної кредитно-фінансової чи іншої установи) та надає їі для використання у розслідуванні.

До суб'єктів забезпечення взаємодії при розслідуванні економічних злочинів транснаціонального характеру також слід віднести осіб, які мають спеціальні знання - фахівців, спеціалістів та експертів, які на практиці відіграють важливу роль у розслідуванні економічних злочинів транснаціонального характеру та одночасно представляють відповідні експертні установи.

Узагальнюючи, слід зазначити, що наявність такої кількості державних органів та посадових осіб, які незалежно один від одного забезпечують взаємодію з іноземними компетентними (правоохоронними) органами та посадовими особами, зовсім не вказує на те, що вони діють не узгоджено та не злагоджено. Така ситуація пояснюється тим, що при розслідуванні транснаціональних економічних злочинів, як і при розслідуванні економічних злочинів вчинених на території нашої держави, доволі часто виникає необхідність у використанні та комбінуванні можливостей забезпечення взаємодії, які є у різних уповноважених (центральних) та компетентних органів й посадових осіб. Тому, у діяльності усіх суб'єктів забезпечення взаємодії при розслідуванні транснаціональних економічних злочинів має проявлятись системність. До того ж, на нашу думку, доцільно розділяти заходи, спрямовані на вирішення спільних завдань взаємодії у процесі забезпечення розслідування транснаціональних економічних злочинів та заходи, що забезпечують інформаційний обмін під час розслідування злочинів даної категорії.

Висновки. Враховуючи сучасний стан системи взаємодії при розслідуванні транснаціональних економічних злочинів, основним предметом діяльності центральних органів, спеціалізованих міжнародних організацій та компетентних органів в Україні, $\epsilon$ не спільна діяльність службових осіб під час розслідування таких злочинів, а забезпечення інформаційного обміну, який здійснюється такими особами.

\section{References:}

1. Chornous, Yu. M. (2012). Teoriia i praktyka kryminalistychnoho zabezpechennia dosudovoho slidstva u spravakh pro zlochyny mizhnarodnoho kharakteru [Theory and practice of forensic support of pre-trial investigation in cases of international crimes]. Kyiv: Skif. [in Ukrainian].

2. Lehan, I. M. (2021). Osnovni napriamy y formy mizhnarodnoho spivrobitnytstva shchodo zapobihannia ta protydii transnatsionalnii zlochynnosti [The main directions and forms of international cooperation in preventing and combating transnational crime]. Aktualni problemy derzhavy i prava [Actual problems of the state and law], 90, 89-93. [in Ukrainian].

3. Flisak, K. A. (2013). Ekonomichna dyplomatiia [Economic diplomacy]. Ternopil: Novyi kolir. [in Ukrainian].

4. Kryminalnyi protsesualnyi kodeks Ukrainy, 2012 (Verkhovna Rada Ukrainy) [Criminal Procedure Code of Ukraine, 2012 (Verkhovna Rada of Ukraine)]. Ofitsiynyy sayt Verkhovnoyi Rady Ukrayiny [Official site of the Verkhovna Rada of Ukraine] <https://zakon.rada.gov.ua/laws/show/4651-17\#Text> (2021, November, 10). [in Ukrainian].

\footnotetext{
1 Закон про ратифікаиію Конвениї Ради Свропи про відмивання, пошук, арешт та конфіскацію доходів, одержсаних злочинним шляхом, та про фінансування тероризму 2010 (Верховна Рада України). Офіџійний сайт Верховної Ради України <https://zakon.rada.gov.ua/laws/show/2698-17\#Техt> (2021, листопад, 11).
} 
5. Viazovchenko, O. V. (2018). Osoblyvosti spivpratsi Ukrainy z mizhnarodnymy orhanizatsiiamy pid chas rozsliduvannia ukhylen vid splaty podatkiv transnatsionalnoho kharakteru [Features of Ukraine's cooperation with international organizations during the investigation of tax evasion of a transnational nature]. Naukovyi visnyk Uzhhorodskoho natsionalnoho universytetu [Scientific Bulletin of Uzhgorod National University], 48, 99-102. [in Ukrainian].

6. Karpenko, Ye. M. (2011). Uchast Yevropolu v zapobihanni ta protydii transnatsionalnii zlochynnosti: pravovi ta orhanizatsiini zasady [Europol's involvement in preventing and combating transnational crime: legal and organizational framework]. Naukovyi visnyk Kyivskoho natsionalnoho universytetu vnutrishnikh sprav [Scientific Bulletin of Kyiv National University of Internal Affairs], 2, 322-328. [in Ukrainian].

7. Zakon pro ratyfikatsiiu Konventsii Rady Yevropy pro vidmyvannia, poshuk, aresht ta konfiskatsiiu dokhodiv, oderzhanykh zlochynnym shliakhom, ta pro finansuvannia teroryzmu, 2010 (Verkhovna Rada Ukrainy)

[Law on Ratification of the Council of Europe Convention on Laundering, Search, Seizure and Confiscation of the Proceeds from Crime and on the Financing of Terrorism, 2010 (Verkhovna Rada of Ukraine)].

Ofitsiinyi sait Verkhovnoi Rady Ukrainy [Official site of the Verkhovna Rada of Ukraine]

<https://zakon.rada.gov.ua/laws/show/2698-17\#Text> (2021, November, 11). [in Ukrainian]. 